\title{
Soybean Protein Diet Increases Low Density Lipoprotein Receptor Activity in Mononuclear Cells from Hypercholesterolemic Patients
}

\author{
M. R. Lovati, C. Manzoni, A. Canavesi, M. Sirtori, V. Vaccarino, M. Marchi, G. Gaddi, and C. R. Sirtori \\ E. Grossi Paoletti Center, Institute of Pharmacological Sciences, University of Milan, 20129 Milan; \\ Clinica Medica Generale II, University of Bologna, Italy
}

\begin{abstract}
The effect of two diets containing different protein sources (animal vs. soybean) on the low density lipoprotein (LDL) receptor activity was tested in freshly isolated mononuclear cells from 12 individuals with severe type II hyperlipoproteinemia. The two diets, both taken for $4 \mathrm{wk}$ in a crossover design were of otherwise identical composition. During the soybean protein diet period, total cholesterol was reduced by $15.9 \%$ and LDLcholesterol by $16.4 \%$. The diet containing animal proteins exerted no significant change in plasma lipid levels vs. the baseline findings. The soybean diet regimen dramatically affected the degradation of LDL by mononuclear cells. Degradation was increased 16-fold vs, the basal activity and 8-fold compared with the standard low lipid diet with animal proteins. There was, however, no clear relationship between the reduction of total and LDL-cholesterolemia and the increased LDL degradation. These findings confirm similar data previously obtained in cholesterol-fed rats and suggest that some factor/s, most likely of a protein nature, may regulate the expression of lipoprotein receptors in peripheral cells, particularly when receptor activity is suppressed by experimental diets and/or spontaneous hypercholesterolemia.
\end{abstract}

\section{Introduction}

The substitution of animal proteins in the diet with textured proteins from soy exerts a remarkable hypocholesterolemic activity in patients with type II hyperlipoproteinemia $(1,2)$, while being essentially inactive in normolipidemic individuals $(3,4)$. The mechanism/s whereby the soybean diet exerts its metabolic effects have been the object of intensive investigation (5). In particular, in animal models, it has been clearly indicated that only animals fed cholesterol or lipid-rich diets respond with a plasma cholesterol reduction to the experimental regimen (6). In rabbits, an increased sterol excretion (both neutral and acidic), as well as an increased sterol turnover in plasma (7), have been described. Although it was suggested,

Address reprint requests to Dr. Lovati, Institute of Pharmacological Sciences, University of Milano, via A. del Sarto 21, 20129 Milano, Italy.

Received for publication 7 January 1987 and in revised form 12 May 1987.

J. Clin. Invest.

(c) The American Society for Clinical Investigation, Inc. 0021-9738/87/11/1498/05 \$2.00

Volume 80, September 1987, 1498-1502 based on animal findings, that peptide products from the digestion of soy proteins may increase fecal steroid output (8), our studies on cholesterol turnover and excretion in type II patients treated with the soybean diet, failed to show signifcant changes either in turnover or in excretion (9).

In the search for alternative mechanism/s that might affect cholesterol metabolism during the experimental regimen, we recently examined the regulation of high affinity receptors for low density lipoproteins (LDL) in rodent liver, during a cholesterol-rich regimen with casein and with soy protein (10). In these animals, as expected, a cholesteremic regimen signifcantly suppressed liver LDL receptors when administered in the presence of casein, a prototype animal protein (11). In contrast, when the same regimen was given with soy proteins, LDL binding to liver membranes was unaffected (10).

These findings suggested that the mechanism by which the soybean diet reduces cholesterolemia might be by way of an improved LDL receptor function, even in the presence of spontaneous or induced plasma cholesterol elevations. A recent study in normal volunteers (12) indicates that the addition of exogenous cholesterol to the diet leads to a rise of total and LDL-cholesterolemia when animal proteins are given concomitantly; when, however, the experimental diet is soy protein based, a reduction of LDL and an increase of high density lipoprotein (HDL) cholesterol levels are recorded. For these reasons, we decided to carry out a controlled evaluation of the LDL receptor activity in type II patients, receiving either a diet with predominant animal proteins or a diet with textured soy proteins (2). In order to achieve the highest possible similarity between the two regimens, some exogenous cholesterol was added to the soybean protein diet that, on the other hand, was totally identical in percentage composition to the diet with animal proteins. Receptor activity was monitored in freshly isolated mononuclear cells, which provide a reliable model of liver LDL receptor function in vivo (13).

\section{Methods}

12 patients ( 7 females and 5 males), ranging in age between 26 and 64 $\mathrm{yr}, 10$ of whom were from the Milan Center and 2 from Bologna, took part in this study. All the patients had been extensively investigated in our Centers, and all had received some prior drug treatment(s) for hypercholesterolemia. While on a diet with a high polyunsaturated/ saturated (P/S) ${ }^{1}$ ratio, their cholesterolemia consistently exceeded 300 $\mathrm{mg} / \mathrm{dl}$, with triglycerides in the normal range. All subjects had not taken any drug affecting intermediary metabolism in the 2 mo before

1. Abbreviations used in this paper: $\mathrm{P} / \mathrm{S}$, polyunsaturated/saturated fatty acid ratio; TG, triglycerides; TVP, textured vegetable proteins. 
this study. The mean age of the participating patients was $45 \pm 3.6 \mathrm{yr}$ (range, 26-64), mean body weight was $61.4 \pm 1.7 \mathrm{~kg}$ (range, 53-72), total cholesterol $409.9 \pm 25.6 \mathrm{mg} / \mathrm{dl}$ (range, 305-610), HDL-cholesterol $49.2 \pm 3.3 \mathrm{mg} / \mathrm{dl}$ (range, 38-68), triglycerides (TG), $124.2 \pm 15.4 \mathrm{mg} / \mathrm{dl}$ (range, 47-216).

Each patient was interviewed in order to calculate the daily energy requirement and all were monitored for 1 mo on a diet with animal proteins and with a $\mathrm{P} / \mathrm{S}$ ratio around 2.0. After this, they entered the crossover protocol, comparing a low lipid diet with animal proteins and an identical diet with textured vegetable proteins (TVP) from soy. The daily energy intake varied between 1,400 and $2,100 \mathrm{kcal}$, with the following percentage composition: $20 \%$ calories from protein, $26 \%$ from lipids, and 54\% from carbohydrates. Both diets had an elevated $\mathrm{P} / \mathrm{S}$ ratio $(\simeq 2.0)$ and the cholesterol content in both was $\sim 150 \mathrm{mg} / \mathrm{d}$, given as dried egg powder within the TVP regimen (2), which per se does not contain cholesterol. TVP was given in a granulated form (Cholsoy, Gipharmex SpA, Milan, Italy), allowing the preparation of a variety of food items, substituting for meat and dairy products (2).

The experimental protocol called for $4 \mathrm{wk}$ on a low lipid regimen with animal proteins, preceded or followed by 4 wk with the TVP regimen; the patients were randomly assigned to each sequence of treatments. Between the two diets, a period of 3-4 wk was allowed, when the patients were instructed to follow a "prudent" diet (14) with animal proteins and with $<10 \%$ of calories from saturated fat.

Plasma lipid and lipoprotein levels were determined at 2-wk intervals by enzyme methods $(15,16)$, with ultracentrifugal separation of lipoproteins (17).

LDL receptor activity of freshly isolated mononuclear cells was determined before the beginning of the experimental protocol (time 0 ) and at the end of each diet (soybean + cholesterol, low lipid). Venous blood $(70-80 \mathrm{ml})$ was diluted 1:1 in plastic tubes containing EDTA (1 $\mathrm{mg} / \mathrm{ml})$ and the appropriate buffer at $\mathrm{pH} 7.4(d$-glucose $0.1 \%$; $\mathrm{CaCl}_{2} \cdot \mathrm{H}_{2} \mathrm{O} 5 \times 10^{-5} \mathrm{M} ; \mathrm{MgCl}_{2} \cdot 6 \mathrm{H}_{2} \mathrm{O} 9.8 \times 10^{-4} \mathrm{M} ; \mathrm{KCl} 5.4 \times 10^{-3}$ $\mathrm{M}$; Tris $0.145 \mathrm{M}$ ), followed by a further dilution $1: 10$ with saline. Diluted blood was then stratified on Ficoll-Paque (18) $(8 \mathrm{ml}$ of blood and $10 \mathrm{ml}$ of Ficoll). After centrifugation for $40 \mathrm{~min}$ at $1,800 \mathrm{rpm}$ in a refrigerated centrifuge at $10^{\circ} \mathrm{C}$, mononuclear cells were separated at the interphase between Ficoll and plasma. The mononuclear cell band was transferred to plastic tubes containing $13 \mathrm{ml}$ of the above described buffer. After $10 \mathrm{~min}$ centrifugation at $1,400 \mathrm{rpm}$ at $10^{\circ} \mathrm{C}$, the precipitate was washed with buffer and recentrifuged for $10 \mathrm{~min}$ at $1,200 \mathrm{rpm}$. The precipitate was resuspended in medium 199 (Gibco Ltd., Paisley, Scotland) $+2 \%$ bovine serum albumin (BSA). Cells were counted on this suspension, in order to obtain $4 \times 10^{6}$ cell samples in a $0.3-\mathrm{ml}$ volume of medium $199+$ BSA $2 \%$

Receptor activity was measured by incubating mononuclear cells from the patients before and after the dietary treatments with ${ }^{125}$ labeled LDL from normal donors (19), and expressed as LDL degradation. For each experiment, mononuclear cells were divided into four samples to determine total degradation, four samples for the assay of nonspecific degradation, and three "blank" samples. Each sample was placed in multiculture cell plates (cell wells, Corning Glass Works, Corning, NY) with $15-\mathrm{mm}$ diam well. To each well were added $4 \times 10^{6}$ mononuclear cells, suspended in $0.3 \mathrm{ml}$ of medium $199+2 \%$ BSA and $25 \mu \mathrm{g}$ of ${ }^{125} \mathrm{I}-\mathrm{LDL}$, in the absence or presence of $500 \mu \mathrm{g}$ of unlabeled LDL added for the determination of the nonspecific binding. A final volume of $1 \mathrm{ml}$ was reached in each well with medium $199+2 \%$ BSA. The culture plates were incubated for $4 \mathrm{~h}$ in an atmosphere of $5 \% \mathrm{CO}_{2}$ at $37^{\circ} \mathrm{C}$. The contents of each well were then transferred to Eppendorf tubes and centrifuged for $10 \mathrm{~min}$ at $10,000 \mathrm{rpm}$ in a microfuge 12 , (Beckman Instruments, Inc., Palo Alto, CA). The pellets were digested with $1 \mathrm{ml}$ of $0.1 \mathrm{~N} \mathrm{NaOH}$ overnight at $37^{\circ} \mathrm{C}$ for protein determination (20). To $0.8 \mathrm{ml}$ of the supernatants, $0.2 \mathrm{ml}$ of $50 \%$ TCA was added followed by boiling, up to complete precipitation of the macromolecules, and centrifugation for $10 \mathrm{~min}$ at $10,000 \mathrm{rpm}$. The supernatants were added with $10 \mu \mathrm{l}$ of $\mathrm{KI} 40 \%$ and $50 \mu \mathrm{l}$ of $\mathrm{H}_{2} \mathrm{O}_{2} 30 \%$ to oxidize iodide to iodine; after extraction with $2 \mathrm{ml}$ chloroform, $0.2 \mathrm{ml}$ of the aqueous phase, containing exclusively ${ }^{125}$ I monoiodine, was counted for radioactivity.

Specific degradation was calculated by subtracting from the total the nonspecific degradations, represented by TCA soluble radioactivity in the respective samples after correction with appropriate blanks.

Statistical analysis of the data was carried out by ANOVA after logarithmic transformation of the data, by evaluating the significance of the effect between sequences ( $1 \mathrm{df}$ ), subjects within sequences ( $6 \mathrm{df})$, residual ( $30 \mathrm{df})$. The level of significance was then determined by Student's $t$ test as $t=$ effect/SEM (21).

\section{Results}

The soybean diet regimen significantly lowered total cholesterolemia both when given first and after the standard low lipid diet with animal proteins. The reduction was, respectively, of $-18.1 \%$ and of $-13.7 \%$ in the two sequences, whereas the effects of the low lipid regimen vs. baseline were negligible (Fig. 1). Similarly, LDL-cholesterol was reduced by $16.4 \%$ (average of the two sequences). Of the 12 treated patients, 7 had an LDL cholesterol reduction in the excess of $15 \%, 1$ of $10 \%$, whereas 1 showed essentially no change of LDL-cholesterolemia vs. the standard low lipid diet with animal proteins. There was no modification of either triglyceridemia or HDLcholesterol in the whole group of participating patients. Body weight of the patients was stable throughout the study.

LDL degradation in mononuclear cells was dramatically affected by the soybean diet regimen. Data, expressed as ng of ${ }^{125} \mathrm{I}$-LDL degraded/mg of cell protein/h, indicate a highly significant increase of degradation, both as compared with basal activity (16-fold) and as compared with the standard low lipid diet with animal proteins (8-fold) (Fig. 2). The standard low lipid diet only determined a rise of receptor activity in four patients, of a modest degree. In the six patients who received the low lipid diet after the soybean regimen, receptor activity fell back to basal levels.

When examining individual changes of total cholesterolemia (reflecting the reduction of LDL-cholesterol) vs. changes in receptor activity, it was apparent that the low lipid diet was virtually ineffective on both parameters, whereas the soybean regimen increased receptor activity far in excess of the comparative standard regimen. It should be noted that receptor activi-

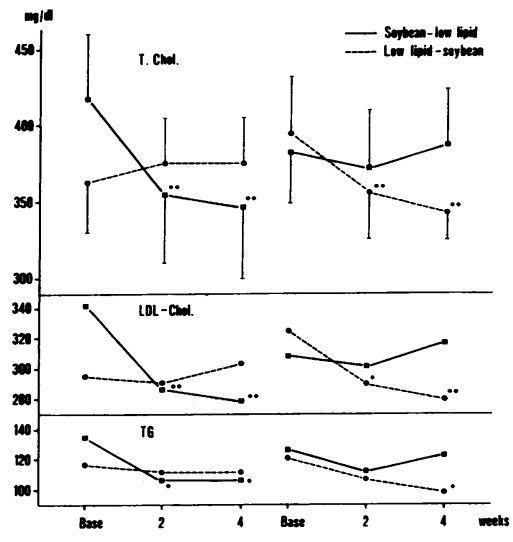

Figure 1. Plasma total cholesterol (T. Chol.), TG, and LDL-cholesterol levels in the 12 participating type II patients during a crossover study, comparing a standard low lipid diet with animal proteins and a soybean diet with added cholesterol. The two dietary sequences were: soybean-low lipid and low lipid-soybean. Each point represents the mean $( \pm$ SEM in the case of total cholesterol) for $n=6$ patients. ${ }^{*} P<0.05 ;{ }^{* *} P<0.001$ vs. the respective baseline levels. 


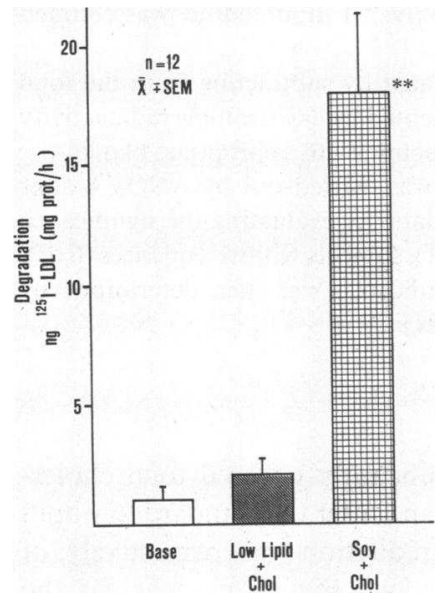

Figure 2. Degradation of ${ }^{125} \mathrm{I}$ LDL by freshly isolated mononuclear cells from type II hypercholesterolemic patients, before and after the dietary treatment with a low lipid diet or with a soybean protein diet with identical cholesterol contents. ${ }^{* *} P<0.01$.

ties in normolipidemic individuals examined in this laboratory $(6.11 \pm 1.7 \mathrm{ng} / \mathrm{mg}$ protein degraded $/ \mathrm{h}, n=6)$, are in a similar range as reported by other authors $(13,22)$. There was no clear relationship between the reduction of cholesterolemia and the increase of LDL degradation (Fig. 3). In particular, in two subjects, both with severe type II disease, results were grossly discrepant. Patient indicated with $\square$ in Fig. 3 experienced a dramatic reduction of total $(-28.6 \%)$ and LDL-cholesterol $(-31.4 \%)$ levels. In spite of this, LDL degradation did not change (Fig. 4). Phenotyping of this patient (courtesy of Dr. J. L. Goldstein, Texas Southwestern University, Dallas, TX) disclosed a reduction of LDL binding and degradation in fibroblasts to, respectively, 41 and $64 \%$ of normal, consistent with a diagnosis of heterozygous type II hyperlipoproteinemia (23). Another patient (*) experienced instead a negligible re. duction of cholesterolemia during the soybean regimen; LDL degradation was however markedly increased (from a baseline

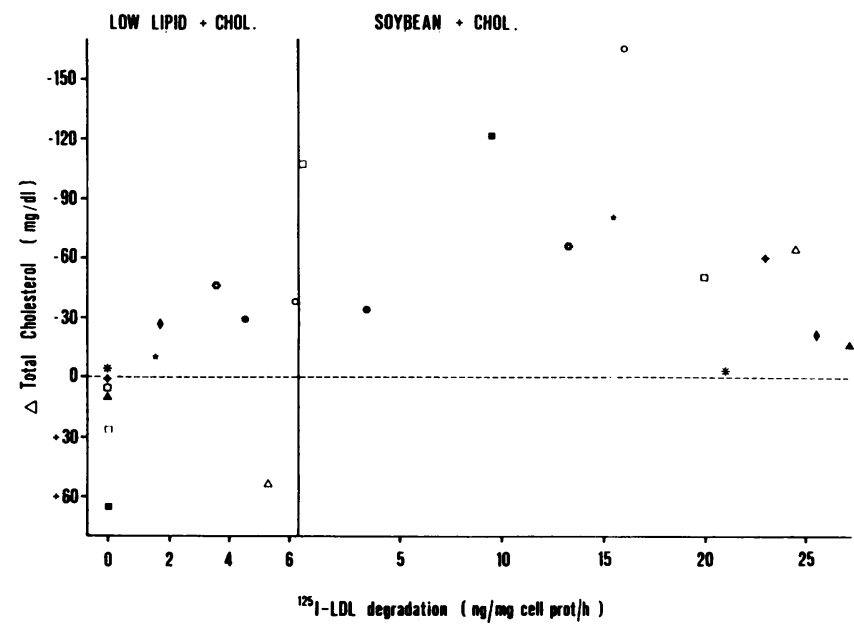

Figure 3. Individual changes of total cholesterolemia and of LDL receptor activity (expressed as LDL degradation), at the end of each dietary period, vs. similar findings at the start of the study. Each individual patient is indicated with a different symbol. Minimal changes of LDL degradation occurred at the end of the low lipid diet, whereas degradation was generally dramatically increased at the end of the soybean diet, with one exception (see Fig. 4).

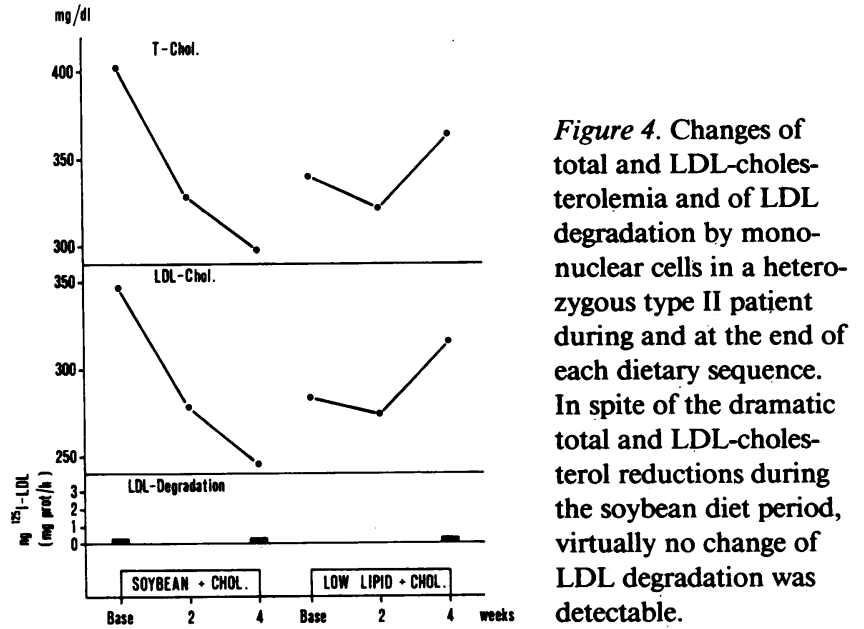

of 0 up to $21.3 \mathrm{ng} / \mathrm{mg}$ protein per $\mathrm{h}$ ). This patient has a familial disease and suffered a myocardial infarction at age $34 \mathrm{yr}$; fibroblast typing was not carried out.

\section{Discussion}

The cholesterol lowering activity of the soybean protein diet in patients with severe type II hyperlipoproteinemia was confirmed in the present study and was associated with a remarkable up regulation of high affinity receptors for LDL in mononuclear cells. In these patients the LDL receptor activity, in the basal state, is very low or absent (24); this situation, according to most authors (13), reflects the condition of liver cells, when exposed to elevated LDL concentrations. Another objective of this study was to establish the activity of the dietary substitution, when in the presence of a similar cholesterol intake, as in a standard low lipid diet with animal proteins. Although, from our early studies, it was clearly shown that the addition of large cholesterol loads $(500 \mathrm{mg} / \mathrm{d})$ does not impair the hypocholesterolemic activity of the soybean diet (1), it was frequently objected that an adequate comparison should involve only diets with an identical lipid composition (25). The reported findings, therefore, also confirm the recent observation that the dietary addition of cholesterol to normal volunteers only increases cholesterolemia within a diet with animal proteins (12). When additional cholesterol was given to normolipidemic volunteers receiving a standard American diet, the expression of high affinity receptors for LDL in mononuclear cells was dramatically reduced (26).

Previous studies on the effects of different diets on LDL receptor activity in mononuclear cells have been limited. In one, as above reported, a down regulatory activity of cholesterol could be shown (26); in another, part of the Oslo Study of Cardiovascular Prevention, a low lipid diet led, in some individuals, to a moderately increased degradation of LDL by mononuclear cells (27). Somewhat more consistent data are provided by studies on the LDL receptor expression after hypolipidemic drugs. In particular, it appears that the reduction of cholesterolemia by anion exchange resins is closely linked to an activation of LDL receptors, although data from individual patients (cholesterol reduction vs. increased LDL receptor activity) have not been reported (22). The same authors more 
recently described similar findings with the inhibitor of cholesterol biosynthesis mevinolin (28).

In this study, the degradation of LDL by mononuclear cells was consistently elevated by the soybean protein diet, to an activity about eightfold higher than that achieved by a standard low lipid diet with animal proteins. There was, however, no significant correlation between the increased LDL receptor activity and the reduction of total or LDL-cholesterolemia. The activation of LDL receptors in these cells is far in excess of that described by Sundberg and Illingworth (22) with colestipol treatment, while achieving a similar degree of mean plasma cholesterol reduction. Indeed, LDL receptor activity after the dietary treatment was, on the average, significantly higher than detected in normolipidemic subjects in our laboratory and elsewhere $(13,22,25)$. One exception to this general pattern was provided by a patient with documented heterozygous type II disease in whom, in spite of a remarkable reduction of cholesterolemia, no increase of LDL degradation in mononuclear cells could be detected. To rule out the possibility of a laboratory error, LDL degradation was determined twice in this patient (data not shown), both on the soybean and on the low lipid regimens, in all cases confirming the absence of receptor activation.

Since cholesterol homeostasis in freshly isolated cells may be influenced by other factors besides cholesterolemia, i.e., changes in LDL composition (29) or in the distribution of the different LDL subfractions (30), it is possible that receptor activity, as determined in mononuclear cells, may not provide a full reflection of LDL receptors in the liver. Although not characterized in this study, the composition of LDL does not appear to be markedly altered by the soybean diet (9); moreover, comparative data on the cellular metabolism of LDL from normals and from type II patients have not shown dramatic differences (31). Since the only patient with a discrepant response was a heterozygous type II individual, it might be suggested that receptor up regulation after the experimental diet should not take place in this type of patients. However, although a complete characterization was not carried out, at least three other patients had a genetic pedigree corresponding to type II heterozygosity, and all three conformed with the general pattern of response. We have recently reported the effectiveness of the dietary regimen in a child with homozygous, receptor-deficient type II disease (32), and similar data have been provided by another European pediatrician (33). It should be stressed that LDL from normolipidemic donors were used for the degradation studies, thus ruling out the possibility of a faulty interaction with cell receptors by hypercholesterolemic LDL (34).

Based on our prior study in cholesterol-fed rats, where the activity of liver $\beta$-VLDL receptors was enhanced by soy proteins in the presence of a massive cholesterol intake (10), it may be surmised that some component/s of the experimental diet may affect receptor expression per se. Data from rabbit experiments by Kritchevsky et al. (35) have indicated that the arginine richness of the soybean diet may be responsible for the cholesterol lowering activity and that this activity may be counteracted by adding lysine to the experimental diet; the responsibility of a high arginine/lysine ratio has not been, however, confirmed by experiments with mixed aminoacid diets (36). The hypothesis that some specific peptide component/s may be responsible for the cholesterol lowering activity and, in addition, for the described up regulation of LDL receptors, has been suggested (37) and should be the object of future experimental work.

\section{Acknowledgments}

Dr. R. Illingworth (University of Oregon) is gratefully acknowledged for his helpful advice in the techniques of lymphocyte separation and LDL binding. Dr. G. C. Naccari (Gipharmex SpA, Milan) kindly provided the textured soy product for this study.

Supported in part by the Consiglio Nazionale delle Ricerche of Italy, PF Ingegneria Genetica e Basi Molecolari delle Malattie Ereditarie.

\section{References}

1. Sirtori, C. R., E. Agradi, F. Conti, E. Gatti, and O. Mantero. 1977. Soybean-protein diet in the treatment of type II hyperlipoproteinemia. Lancet. i:275-277.

2. Sirtori, C. R., E. Gatti, O. Mantero, F. Conti, E. Agradi, E. Tremoli, M. Sirtori, L. Fraterrigo, L. Tavazzi, and D. Kritchevsky. 1979. Clinical experience with the soybean protein diet in the treatment of hypercholesterolemia. Am. J. Clin. Nutr. 32:1645-1658.

3. Shorey, R. A. L., B. Bazan, G. S. Lo, and F. H. Steinke. 1981. Determinants of hypocholesterolemic response to soy and animal protein-based diets. Am. J. Clin. Nutr. 34:1769-1778.

4. Van Raaij, J. M. A., M. B. Katan, J. G. A. J. Hautvast, and R. J. J. Hermus. 1981. Effect of casein versus soy protein diets on serum cholesterol and lipoproteins in young healthy volunteers. Am. $J$. Clin. Nutr. 34:1261-1271.

5. Gibney, M. J., and D. Kritchevsky. 1983. Animal and Vegetable Proteins in Lipid Metabolism and Atherosclerosis. Alan R. Liss, Inc., New York.

6. Terpstra, A. H. M., G. van Tintelen, and C. E. West. 1982. The hypocholesterolemic effect of dietary soy protein in rats. $J$. Nutr. 112:810-817.

7. Huff, M. W., and K. K. Carroll. 1980. Effect of the dietary protein on turnover, oxidation and absorption of cholesterol, and on steroid excretion in rabbits. J. Lipid Res. 21:546-558.

8. Yashiro, A., S. Oda, and M. Sugano. 1985. Hypocholesterolemic effect of soybean protein in rats and mice after peptic digestion. $J$. Nutr. 115:1325-1336.

9. Fumagalli, R., L. Soleri, R. Farina, R. Musanti, O. Mantero, G. Noseda, E. Gatti, and C. R. Sirtori. 1982. Fecal cholesterol excretion studies in type II hypercholesterolemic patients treated with the soybean protein diet. Atherosclerosis. 43:341-353.

10. Sirtori, C. R., G. Galli, M. R. Lovati, P. Carrara, E. Bosisio, and M. Galli Kienle. 1984. Effects of dietary proteins on the regulation of liver lipoprotein receptors in rats. J. Nutr. 114:1493-1500.

11. Chao, Y. S., T. T. Yamin, and A. W. Alberts. 1982. Effects of cholestyramine on low density lipoprotein binding sites on liver membranes from rabbits with endogenous hypercholesterolemia induced by a wheat starch-casein diet. J. Biol. Chem. 257:3623-3627.

12. Meinertz, H., K. Nilausen, and O. Faergeman. 1984. Effects of dietary soy protein and casein on plasma lipoproteins in normolipidemic subjects. Circulation. 70:1161. (Abstr.)

13. Mistry, P., N. E. Miller, M. Laker, W. R. Hazzard, and B. Lewis. 1981. Individual variation in the effects of dietary cholesterol on plasma lipoproteins and cellular cholesterol homeostasis in men. Studies of low density lipoprotein receptor activity and 3-hydroxy-3methylglutaryl coenzyme A reductase activity in blood mononuclear cells. J. Clin. Invest. 67:493-502.

14. Grundy, S. M., D. Bilheimer, H. Blackburn, W. V. Brown, P. O. Kwiterovich, Jr., F. Mattson, G. Schonfeld, and W. H. Weichman. Rationale of the diet-heart statement of the American Heart 
Association. Report of Nutrition Committee. Circulation. 65:839A854A.

15. Röschlau, P., E. Bernt, and W. Gruber. 1974. Enzymatische Bestimmung des Gesamtcholesterin im Serum. J. Clin. Chem. Clin. Biochem. 12:403-407.

16. Bucolo, G., and H. David. 1973. Quantitative determination of serum triglycerides by use of enzymes. Clin. Chem. 19:476-482.

17. Havel, R. J., H. A. Eder, and J. H. Bragdon. 1974. The distribution and chemical composition of ultracentrifugally separated lipoproteins in human serum. J. Clin. Invest. 34:1345-1354.

18. Böyum, A. 1968. Isolation of mononuclear cells and granulocytes from human blood. Isolation of mononuclear cells by one centrifugation, and of granulocytes by combining centrifugation and sedimentation at 1 g. Scand. J. Clin. Lab. Invest. 58:1465-1474.

19. Ho, Y. K., M. S. Brown, D. W. Bilheimer, and J. L. Goldstein. 1976. Regulation of low density lipoprotein receptor activity in freshly isolated human lymphocytes. J. Clin. Invest. 58:1465-1474.

20. Lowry, O. H., N. J. Rosebrough, A. L. Farr, and R. J. Randall. 1951. Protein measurement with the Folin phenol reagent. J. Biol. Chem. 193:265-275.

21. Armitage, P. 1971. Statistical Methods in Medical Research. Blackwell Scientific Publications, Oxford. 246.

22. Sundberg, E. E., and D. R. Illingworth. 1983. Effects of hypolipidemic therapy on cholesterol homeostasis in freshly isolated mononuclear cells from patients with heterozygous familial hypercholesterolemia. Proc. Natl. Acad. Sci. USA. 80:7631-7635.

23. Goldstein, J. L., and M. S. Brown. 1977. The low-density lipoprotein pathway and its relation to atherosclerosis. Annu. Rev. Biochem. 46:897-930.

24. Bilheimer, D. W., Y. K. Ho, M. S. Brown, R. G. W. Anderson, and J. L. Goldstein. 1978. Genetics of the low density lipoprotein receptor. Diminished receptor activity in lymphocytes from heterozygotes with familial hypocholesterolemia. J. Clin. Invest. 61:678-696.

25. Van Raaij, J. M. A., M. B. Katan, and G. A. J. Hautvast. 1982. Influence of diets containing casein, soy isolate and concentrate on serum cholesterol and lipoproteins in middle-aged volunteers. Am. J. Clin. Nutr. 35:925-934.

26. Applebaum-Bowden, D., S. M. Haffner, E. Hartsook, K. H. Luk, J. J. Albers, and W. R. Hazzard. 1984. Down-regulation of the low density lipoprotein receptor by dietary cholesterol. Am. J. Clin. Nutr. 39:360-367.

27. Leren, T. P., I. Hjermann, K. Maartmann-Moe, S. L. Beckmann, P. Leren, and K. Berg. 1985. Effect of lipid lowering diet on low density lipoprotein receptor activity in freshly isolated peripheral blood mononuclear cells. Acta Med. Scand. 218:41-49.

28. Hagemenas, F. C., S. Lindsay, and D. R. Illingworth. 1986. The influence of mevinolin on cholesterol homeostasis in mononuclear leukocytes from patients with familial hypercholesterolemia. Circulation. 74:797. (Abstr.)

29. Zechner, R., H. Dieplinger, A. Roscher, F. Kempler, and G. M. Kostner. 1982. The role of lecithin: cholesterol acyltransferase for the low density lipoprotein composition and specific binding to the $B$ receptor. Biochim. Biophys. Acta. 712:433-435.

30. Fisher, W. R. 1983. Heterogeneity of plasma low density lipoproteins: manifestations of the physiologic phenomenon in man. Metab. Clin. Exp. 32:283-291.

31. Goldstein, J. L., and M. S. Brown. 1973. Familial hypercholesterolemia. Identification of a defect in the regulation of 3-hydroxy-3methylglutaryl coenzyme A reductase activity associated with overproduction of cholesterol. Proc. Natl. Acad. Sci. USA 70:2804-2808.

32. Gaddi, A., G. C. Descovich, G. Noseda, C. Fragiacomo, A. Nicolini, G. Montanari, G. Vanetti, M. Sirtori, E. Gatti, and C. R. Sirtori. 1987. Hypercholesterolemia treated by soybean protein diet. Arch. Dis. Child. 62:274-278.

33. Widhalm, K. 1986. Pediatric guidelines for lipid reduction. In Lipoprotein and Atherosclerosis: Current Views, Future Trends, Helsinki, Finland. Abstr. 11.

34. Vega, G. L., and S. M. Grundy. 1986. In vivo evidence for reduced binding of low density lipoproteins to receptors as a cause of primary moderate hypercholesterolemia. J. Clin. Invest. 78:14101414.

35. Kritchevsky, D., S. A. Tepper, S. K. Czarnecki, and D. M. Klurfeld. 1982. Atherogenicity of animal and vegetable protein. Influence of the lysine to arginine ratio. Atherosclerosis. 41:429-431.

36. Huff, M. W., and K. K. Carroll. 1980. Effects of dietary proteins and amino acid mixtures on plasma cholesterol levels in rabbits. J. Nutr. 110:1676-1685.

37. Redgrave, T. G. 1984. Dietary proteins and atherosclerosis. Atherosclerosis. 52:349-351. 